\title{
The Content of Non Verbal Communication Values in the Book Sulam Al-Munawwaraq Fil 'Ilmi Mantiq
}

\author{
Halimatussa'diah \\ Faculty of Da'wah and Communication, Institute of Islamic Religion (IAI) Al-Aziziyah Samalanga, Bireun, \\ Aceh, Indonesia \\ dsnhalimah02@gmail.com
}

\begin{abstract}
Non-verbal communication is often used to describe feelings, emotions, and others. Non-verbal communication can strengthen and complement verbal communication. Therefore, in life must combine the two communications. Like the nazham contained in the al-Munawwaraq embroidery Fil Ilmi Mantiq. Which explains about lafadh and ghairu lafadh both are related to one another. So that both the majority of students and some teachers who study the book sulam al-Munawwaraq Fil 'Ilmi Mantiq do not know that there is a discussion of communication in the nazham. The phenomenon finally motivated a study entitled "Analysis of Non Verbal Communication Content in the book al-Munawwaraq Fil" Ilmi Mantiq". This study is focused only on a nazham found in the book sulam al-Munawwaraq Fil 'Ilmi Mantiq, the nazham is conducted using the library research method, namely research carried out using literary literature, such as the yellow books, notes, and previous research report. This study yielded several answers, namely non-verbal communication in the book Sulam AlMunawwaraq is found in the nazham was violated, as well as the value of non-verbal communication in the book sulam alMunawwaraq Fil 'Ilmi Mantiq namely in the discussion of ghairu lafdhiyyah. The same is true of non-verbal communication put forward by communication experts. Then it can be concluded that the non-verbal communication contained in the book sulam alMunawwaraq Fil 'Ilmi Mantiq is exactly the same as the non-verbal communication stated by communication experts.
\end{abstract}

Keywords non verbal conmunication; values, SulamA-Mnawwaraq

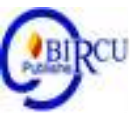

\section{Introduction}

Communication is very important in all lines of life without the existence of human communication in this world can not be interconnected with one another. Because humans are social beings, they cannot live alone. Therefore, this life is needed communication both verbal and non verbal. From ancient times until now humans have been connected through communication to obtain information and matters relating to human life. This is where the emergence of verbal and non verbal communication. Non-verbal communication is also very important to understand because it is widely used in displaying or maintaining one's image. In a presidential election campaign, for example, a presidential candidate must present himself with a certain figure as a non-verbal message that will be delivered to the prospective voter. With non-verbal communication also a teacher explains the subject matter to students in addition to using verbal communication. Likewise, soap operas with non-verbal communication are also soap operas that we see more we can understand the meaning. 
Non-verbal communication is communication that uses motion, body language cues, facial expressions, and eye contact, the use of objects such as clothing, haircuts, and so on. Symbols and ways of speaking such as intonation, emphasis, sound quality, style, emotions, and speaking style. Non-verbal communication complements verbal communication because not all humans are able to understand speech alone but must be equipped with motion or the like. Therefore, skills are needed to interpret and understand these nonverbal messages.

In the book al-Munawwaraq Fil 'Ilmi Mantiq there is also a discussion of communication that is lafadh at the nazham (stanza) which reads:

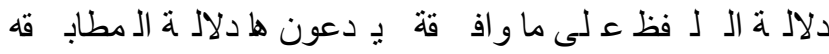

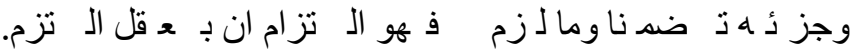

Dilalah is a hint of the word used for a meaning, according to the instructions attached to it (according to the characters attached to it).

If dalalah (word hint) used for something is only in accordance with the parts of its meaning, then the name is dalalah tadhamuniyyah. If it is in accordance with something that is closely related to the meaning contained therein, then the name is iltizamiyyah.

One of the communications contained in the book Sulam Al-Munawwaraq is ghairu lafadh (non verbal). Ghairu lafadh (non verbal) is an indicator for something that is not in the form of words or sounds. In the explanation of ghairu lafadh there are also classifications, namely: Ghairu lafdhiyah Thaba'iyah, ghairu lafdhiyah 'Aqliyah, and ghairu lafdhiyah" Adiyyah. Likewise with lafadh (verbal) classification is also the same as ghairu lafadh (nonverbal) and more detailed discussion in the book Sulam Al-Munawwaraq, because indeed the discussion discussed in this discussion is entirely on communication lafadh (verbal).

As for the phenomenon that is happening now that many among students and teachers do not know that the discussion on the nazham is a discussion of communication, both verbal and non verbal, especially regarding non-verbal communication not knowing at all only a portion of students and teachers who do not know. Though the discussion is a lot happening in everyday life, both verbal and non verbal. They only study only the verbal discussion because what is discussed in the book is only verbal communication which is non-verbal not too studied or discussed because learning in the book is popular with the difficulty in understanding the intentions contained in the book, especially regarding discussion the communication in the book Sulam Al-Munawwaraq is very unthinkable even though all the contents in the book are all in daily life. In the world of lectures is called philosophy or the science of logic.

Starting from this problem the author wants to examine the study of non-verbal communication in the book Sulam al-Munawwaraq Fil 'Ilmi Mantiq which is no less important than verbal communication. This is where the author's interest is to study the discussion of non-verbal communication in the contents of the book Sulam al-Munawwaraq Fil 'Ilmi Mantiq, because it includes a uniqueness that is not thought of by many people. The discussion in this paper is how to analyze the content of non-verbal communication in the book Sulam al-Munawwaraq Fil 'Ilmi Mantiq, what are the contents of non-verbal communication, and what are the forms of non-verbal communication in the book Sulam alMunawwaraq Fil' Ilmi Mantiq and etc. 


\section{Review of Literatures}

On the basis of theory in a scientific work, the author explains the definitions and theories that are relevant from the assumptions of adjacent research objects to avoid misunderstanding in understanding the title of this study, it is necessary to explain the terms to give a clearer picture of the meaning of words words contained in the title of this description. The terms in question are as follows:

\subsection{Communication}

Communication is the contact relationship between humans, both individuals and groups. In everyday life, it is realized or not communication is a part of human life from birth to communicate with the environment. The first movement and tears at birth are a sign of communication.

Eduard Depari gives the understanding of communication is the process of delivering ideas, hopes, messages conveyed through certain symbols that contain meaning, carried out by delivering messages (source, communicator, sender) aimed at the recipient of the message or receiver communicator or audience with the intention of achieving togetherness (commonnees). In the process of communication togetherness is sought through the exchange of opinions, the delivery of information or changes in behavior / attitude, in essence every communication process, whether it is the process of interpersonal communication or mass communication (mass communication) there are always four elements or components such as these above. The elements and components can still be added by two more elements or components, namely the effect of influence and feedback (feedback, feedback). The communication referred to here is non-verbal communication.

\subsection{Non Verbal}

Non-verbal is using gestures, body language, facial expressions and eye contact, the use of objects such as clothing, haircuts, and so on. Symbols and ways of speaking such as intonation, emphasis on sound quality, style, emotions, and speaking style.

\subsection{Dilalah Ghairu Lafdhiyyah Definition}

Dilalah in terms of language comes from Arabic, namely daala-yadulu-dilalah which means instructions or that shows. Dilalah (marker) in Arabic is ad-dilalah if interpreted in terms of etymology is al-dal (pointer) to al-madlul (designated object). In the book of sharah al-Quwaisiny 'ala matan al-sulam fi al-Manthiq it has been explained that to do is to understand something from something else, whether that understanding is by doing or not by doing. The first something is called Al-dall (instructions, signs, lights, or members of the proposition), and everything the second is called madlul (designated or explained).

Meanwhile, according to Abi Hilal al-Askari defines dilalah as follows:

Dilalah is a unit of observed phenomena in shaping scientific knowledge.

Example:

a. The smoke behind the hill means that there is a fire underneath. In this case the smoke is called dal or dalil (which shows or hints). While the fire is called madlul (designated or explained).

b. The roar of a tiger in a bush is dilalah (hint or sign) that there is a tiger inside the bush. The roar of a tiger is called dal or dalil. While the presence of tigers is called madlul. 


\subsection{The Book Al-Munawwaraq Fil 'Ilmi Mantiq}

The Book Sulam Al-Munawwaraq Fil 'Ilmi Mantiq is one of the works written by Sheikh Abdurrahman Al Akhdary which contains science mantiq (logic). This book is the main reference as well as the object of this research study.

The Book Sulam Al-Munawwaraq Fil 'Ilmi Mantiq consists of two words namely Sulam and al-Munawwaraq. Sulam means a tool used to climb something high. Whereas AlMunawwaraq here means something that has been decorated. Sheikh Abdurrahman AlAkhdary named his essay with Sulam Al-Munawwaraq in the hope that this book could be used as one of the disciplines of a tool that could be used as an intermediary for solving complex problems in life.

\section{Research Methods}

This type of research used in this study is library research (literature study), which is a type of research that makes library data as a theory that is studied and tuned in obtaining hypotheses, and conceptions to obtain objective results. With this type of information can be taken completely to determine scientific action in research as an instrument that meets research support standards.

Research in this type takes assumptions based on data that supports to gain creative, and imaginative insights. This is in the form of a comparison of one conception of thought with another productively by leaving the scientific basis. In the research library the author is more focused and dealing directly with relevant liberatul texts without looking for data anywhere. So that researchers only conduct research through literatul-literatul in the library.

The primary data in this study is the Book Sulam al Munawwarq Fil 'Ilmi Mantiq. Secondary data in this study will be taken from literatul which discusses non-verbal communication in the book Al Munawwaraq Fil 'Ilmi Mantiq in general, which the author gets in the literature or other places. Like, Syarah Quwaisuni, Idhahul Mubham, Hasyiah Sulam al Malawi.

\section{Discussion}

\subsection{Author Profile of the Book Sulam Al-Munawwaraq Fil 'Ilmi Mantiq and Study Patterns in the Book Sulam Al-Munawwaraq Fil' Ilmi Mantiq}

One of the books that become a mandatory guide in learning the science of mantiq is the Book Sulam Al-Munawwaraq which is a book in the form of nazham which is a guide for beginners of the science of mantiq. In every Islamic boarding school, especially in Aceh, and generally throughout the Islamic boarding school this book becomes the curriculum in every Islamic boarding school in learning science. This book was compiled by Sheikh Abdur Rahman Al-Akhdari. On this occasion the author would like to present a brief biography of Sheikh Abdur Rahman Al-Akhdari as a research writer in the making of a thesis.

His full name is Abu Yazid Abdur Rahman bin Muhammad ashshugayyra bin Amir alakhdari. Al-Akhdari is assigned to Al-Akhdar, the name of a hill in Algeria (Maroco). From his father's side, he continued until one of the Companions of the Prophet (PBUH), Al-Abbas bin Mirdas bin Abi Amir as-sulami.

There was a difference of opinion among historians about the year of Imam AlAkhdari's birth. According to some historians he was born in the village of Benthious, western Zab, Algeria in $910 \mathrm{H} / 1504 \mathrm{AD}$ and died in $953 \mathrm{H} / 1546 \mathrm{AD}$, another opinion says he was born in $918 \mathrm{H} / 1512 \mathrm{AD}$ and died in 953/1546 AD But if you look at his own statement at the end of the book Sulam Al-Munawwaraq Fil 'Ilmi Mantiq, where he said when he finished 
writing the Matan Sulam book at the age of 21 years in $941 \mathrm{H}$ then it can be concluded that he was born around $920 \mathrm{H}$. He was born in a family environment that holds fast on shara 'and hate acts that violate the book and the Sunnah. His father was a scholar who wrote a devotion to the book Sayidi jalil. His grandfather Sheikh Muhammad bin Amir was also a Sufism scholar. He is a scholar of the Maliky School, this is known from his own work Matan alAkhdary al worship, according to the treatise in fiqh which refers to the Maliki school of thought.

\subsection{The Content of Non Verbal Communication Values in the Book of Sulam Al- Munawwaraq}

As we know, human communication not only uses verbal symbols but also non-verbal symbols. Likewise in interpersonal communication, we not only convey messages verbally, but also non-verbally. Non-verbal messages not only reinforce the verbal messages conveyed, sometimes even convey their own messages. Therefore, skills are needed to interpret and understand these nonverbal messages.

In everyday life there are many non-verbal communications that we often encounter, both directly and indirectly, both consciously and unconsciously, even though it is always in an environment where the conversation is in non-verbal concepts. Everything we do in our daily lives is completely non-verbal communication.

The content of non verbal communication values in the book of Sulam AlMunawwaraq who has been the author of the review is on Nazham

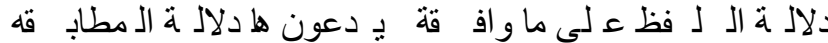

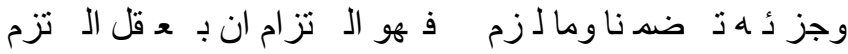

Dilalatul lafdhi 'ala ma wafaqah yad'u naha dilalatal mutabaqah

Wajuz ihi tadhammuna wama lazim fahuwal tizamu and bi' aqlit tuzim

Dilalah is a hint of the word used for a meaning, according to the instructions attached to it (according to the characters attached to it). If dalalah (word hint) used for something is only in accordance with the parts of its meaning, then the name is dalalah tadhamuniyyah. If it corresponds to something closely related to the meaning contained therein, then the name is iltizamiyyah.

In the aforementioned nazham explains that dilalah is a hint of the word used for a meaning. The word dilalah is the masdar form of the word dalla which means to understand something from something else.

Example:

- In the middle of the forest came a roar.

The word "roaring sound", is the dalalah of wild animals in the forest.

- In the darkness of the old house came the sound of screams.

The word "screaming", is the dalalah for humans in the darkness of the old house.

- In the middle of the ruins of high rise buildings, a whimper was heard.

The word "sound whimpering" in the middle of the building, is dalalah for the existence of humans who are still alive in the middle of the ruins of the building.

From the definition of above and its application example, it can be classified into two parts:

1. Dilalah lafdhiyah, ie dalalah in the form of words or lafadz.

2. Dilalah ghairu lafdhiyah, which is dalalah for something that is not in the form of words or sounds. 
Here the author no longer discusses dilalah lafdhiyyah, because the writer only discusses about dilalah ghairu lafdhiyyah.

Dilalah Ghairu Lafdhiyyah was divided into three parts, namely:

a. Dilalah Ghairu Lafdhiyyah or Wadh'iyyah, that is dalalah in the form of something that is natural (natural).

Example:

Cheerful face, an indicator for people whose hearts are feeling happy.

Mirror face, an indicator for people whose hearts are feeling sad or angry.

Nod, an indicator for people who agree.

Shaking his head, an indicator for people who refuse.

If equated with non-verbal communication expressed by communication experts, this communication is included in the type of non-verbal communication on body movements and facial expressions. As we have seen in the above example, the non-verbal communication presented by experts with the non-verbal communication contained in the book of Sulam AlMunawwaraq is exactly the same.

b. Dilalah Ghairu lafdhiyyah 'aqliyah, is an indicator in the form of critical understanding and logical analysis.

Example:

Goats in cages are missing, as an indicator of theft.

The changing universe, as an indicator for the new nature.

Forest fires, an indicator for people who carry fires / set fires there.

Deforestation, an indicator of illegal logging.

Landslides, an indicator for deforested forests.

Likewise, Dilalah Ghairu lafdhiyyah 'aqliyah was carried out as well as non-verbal communication by showing bodily movements to the intended object or it could also be the loss of something that could also be shown that someone was taking the object.

c. Dilalah Ghairu lafdhiyyah 'aqliyah was carried out, namely indicators in the form of symbols that had been mutually agreed upon as an indication for the meaning contained therein.

Example:

The raising of a half-pole, as an indicator for the condolences of large people or public figures or public officials who died.

Rain, as an indicator for plant growth.

Adhan, an indicator for the inclusion of the time to perform the obligatory prayers.

In the types of non-verbal communication there is visual communication, non-verbal communication is the same as what was done Dilalah Ghairu lafdhiyyah 'aqliyah contained in the book of Sulam Al-Munawwaraq.

Regarding non-verbal communication in the book al-Munawwaraq Fil 'Ilmi Mantiq, the classic book or the yellow book written by Imam al-Akhdari is a discussion (indicator). In the discussion of dilalah also a discussion of verbal communication, which was in lafdhiyyah. Lafdhiyyah also has calcifications as well as verbal communication. But here it is not necessary to discuss verbal communication, because the writer makes a study of nonverbal communication only. 
By knowing non-verbal communication in the book al-Munawwaraq Fil 'Ilmi Mantiq, that non-verbal communication that experts pointed out was the first Islamic scientist who had already researched about the communication. As with the types or forms of non-verbal communication experts put forward communication, including:

1. Visual communication.

2. Touch.

3. Chronemic.

4. Body movements.

5. Proxemic.

6. Vocals.

Likewise, non-verbal communication in the book al-Munawwaraq Fil 'Ilmi Mantiq expressed by Shaykh al-Akhdary as well as non-verbal communication expressed by experts. Only the name is different, if in the book al-Munawwaraq Fil Ilmi Mantiq with the term being imposed dilalah ghairu lafdhiyyah means in communication is non verbal communication. Likewise, the classification is exactly the one stated by communication experts. Classification of nonverbal communication in the book al-Munawwaraq Fil 'Ilmi Mantiq, namely:

1. Dilalah ghairu lafdhiyyah Thaba'iyyah.

2. Dilalah ghairu lafdhiyyah 'Aqliyyah.

3. Dilalah ghairu lafdhiyyah 'Adiyyah.

In this way, the nonverbal communication of the experts pointed out with Sheikh alAkhdary was the same. Both in terms of definition, classification and others are also the same. This shows that it was the Islamic scientists who first discovered the theory of communication. Then it was renamed by western communication experts. Until now many theories that have been used are western theories, so many Islamic theories have been omitted from the records of experts or communication figures.

If seen from the history of the rapid development of Islam when it was in Andalusia or Spain now. At that time all corners of the world studied in the city so that many intellectual scholars were born both in the field of medicine, the field of communication and other fields as well. Many scientists were born in Andalusia at that time. Islamic scientists in particular. After a few centuries Islam at that time continued to grow until one third of the Islamic world succeeded. After that there was a conflict between the two parties that caused the Islamic scientists died, then the writings written by Islamic scientists were taken and kept by people who were hostile to Islam at that time. And a library full of books by Islamic scientists was also set on fire. That is where the lost traces of Islamic scientists at that time.

Not long after that, western scientists were born to this day. They changed everything with the name of their own scientist until now. Even though many Islamic scientists have discovered various theories. It all started with the Islamic scientists who studied it, then followed by western experts.

We can conclude that the theory of non-verbal communication put forward by nonverbal communication experts that we know now, apparently has been researched by Islamic scientists who study it. Judging from the year of study of Sheikh al-Akhdary with non-verbal communication experts is very different from the birth of non-verbal communication. 


\section{Conclusion}

The contents of non-verbal communication in the book of Sulam Al-Munawwaraq are only found in the nazham which explains about being done or in the world of research known as indicators. The definition is to understand something from something else. It is from this definition that the birth of ghairu lafdhiyyah is called non-verbal communication.

The forms of non-verbal communication in the book of Sulam Al-Munawwaraq book are as follows:
a. Dilalah ghairu lafdhiyyah taba'iyyah atau wadh'iyyah.
b. Dilalah ghairu lafdhiyyah 'aqliyyah.
c. Dilalah ghairu lafdhiyyah 'adiyyah.

\section{References}

A.W. Widjaya, Komunikasi dan Hubungan Masyarakat, Bumi Aksara,2008.

Ahmad Hatta, Tafsir Qur`an Per kata; Dilengkapi dengan Asbabun Nuzul dan Terjemahan, Jakarta: Maghfirah Pustaka, 2009.

Alex Sobur, Semiotika Komunikasi, Bandung: Remaja Rosdakarya, 2003.

Ami Muhammad, Komunikasi Organisasi, cet II, Jakarta: Bumi Aksara, 1995.

Amin, A. S. 2020. Communication Activities in Mitoni Events in Layansari Village (Study of Communication Ethnography Regarding Communication Activities at the Mitoni Event in Layansari Village, Gandrungmangu District, Cilacap Regency in requesting the safety of Mother and Child). Budapest International Research and Critics InstituteJournal (BIRCI-Journal) (3): 1289-1296.

Ambar, "Model Komunikasi", Jurnal 6 Model-Model Komunikasi Menurut Para Ahli, (online), http/www.pakarkomunikasi.com, diakses tanggal 17 Januari 2020.

Arabiyah Yes, Dilalah dan Macam-macamnya Dalam Ilmu Mantiq, (online), http:/www.arabiyahyes.blogspot.com, diakses tanggal 6 Februari 2020.

Bugin, Metode Penelitian Kualitatif, Jakarta: Pranada Media, 2005.

Dan B. Curtis, dkk, Komunikasi Bisnis dan Profesional, Bandung: Remaja Rosdakarya, 2005.

Dedy Mulyana, Komunikasi Suatu Pengantar, Bandung: Remaja Rosdakarya, 2008.

Devito Joseph A, Komunikasi Antar Manusia, diterjemahkan: Agus Maulana, Jakatra: professional Books, 1997.

Fairus, Kholil, S., and Arifin, Z. 2018. Face, Posture, and Gesture (Study of Kinesik Aspects in Qur'an). Budapest International Research and Critics Institute-Journal (BIRCIJournal) (1): 330-343.

Judi Pearson, Human Communication, New york: Mc Graw Hill Companies, 2003.

Koentjaraningrat, Metode-metode Penelitian Masyarakat, Jakarta: Gramedia Pustaka Utama, 1990.

Komunikasi non verbal, (online), https//id.m.wikipedia.org/wiki/ komunikasi nonverbal, diakses tanggal 21 desember 2019.

Lexy, J moleong, Metode Penelitian Kualitatif, Bandung: Remaja Rosda Karya, 2001.

Mark L. Knapp, dikutip oleh Cangara, Hafied, Pengantar Ilmu Komunikasi, Jakarta Raja Grafindo Persada, 2008.

Muhammad Ma'shum, Zubdatul Mantiqiyyah Teori Berpikir Logic Pengantar Memahami Nadzam Sulam Al-Munawwaraq, Jombang: Darul Hikmah, 2008. 
Muhammad Ma'shum, Zubdatul Mantiqiyyah Teori Berpikir Logic Pengantar Memahami Nadzam Sulam Al-Munawwaraq, Jombang: Darul Hikmah, 2008.

Nana Syodih Sukmadinata, Meteologi Penelitian Pendidikan, Bandung: Remaja Rosda Karya, 2005.

Nuruddin, Sistem Komunikasi Indonesia,Jakarta: Raja Grafindo Persada, 2004.

Nyoman Ktha Ratna, Teori Metode Penelitian Satra, Yogyakarta: Pustaka Pelajar, 2006.

Onong Uchjana Effendy, Ilmu Komunikasi Teori dan Praktek, Bandung: Remaja Rosda karya, 2009.

Paul Ekman dalam Em Griffin, A first Look At CommunicationTheory, dalam Dedy Mulyana, Komunikasi Suatu Pengantar,Bandung: Remaja Rosdakarya, 2008.

Pengertian Komunikasi, (online), http//www.ilmusahid.com/2015/09/PengertianKomunikasi-tujuan-komunikasi.html, diakses tanggal 28 Desember 2019.

Radian, Pesan-Pesan Komunikasi Non Verbal Dalam Melaksanakan Peusijuk (Studi Gampong Meunasah Weh Kec. Jaya Kab. Aceh Jaya), Skripsi IA Al-Aziziyah, 2017, tidak diterbitkan.

Saifullah, Panduan Meteologi Penelitian, Cet. Ke-1, Malang: UIN Press. 2006.

Santri dayah, Syeikh Abdurrahman Al-Akhdary Pengarang kitab Nadham mustajabah Do'a, (online), http:/www.disdikdayah,bandaacehkota.go.id, diakses tanggal 5 Desember 2019.

Sasa Djuarsa Sendjaja, dkk, Pengantar Komunikasi, Jakarta: Universitas Terbuka, 2003.

Soemirat dkk., Dasar-Dasar Public Relations, Bambang Remaja Rosdakarya, 2004.

Suharsimi Arikunto, Prosudur Penelitian Suatu Pendekatan Praktek, Jakarta: Rineka Cipta, 1998.

Syekh Abdurrahman Al Akhdary, Sulam Al Munawwaraq Fil Ilmu Mantiq, Indonesia: AlHaramain, t.t.

Syekh Hasan Darwis Al quwaisuni, Syarah Al-Quwaisuni 'Ala Matan Sulam Fil Mantiq, Indonesia: Al-Haramain, tt.

Taslimuharrom, Metodologi PAKEM, Artikel Pendidikan.

Wardi Bahtiar, Metodologi Penelitian Ilmu Dakwah, Jakarta: Logos Wacana Ilmu, 1987. 